\title{
Pengembangan E-Modul Berbasis Inkuiri Terbimbing Terintegrasi Virtual Laboratory pada Materi Asam Basa Kelas XI SMA/MA
}

\section{Development of E-Modul Based on Integrated Guided Inquiry Virtual Laboratory on Acid-Base Material for Class XI SMA/MA}

\author{
R Oktarina ${ }^{1}$ and Andromeda ${ }^{1 *}$ \\ 1 Pendidikan Kimia, Universitas Negeri Padang, \\ Jl. Prof. Dr. Hamka, Air Tawar Barat, Padang Utara, Sumatera Barat, Indonesia 25171 \\ *andromedasaidir@yahoo.com
}

ARTICLE INFO

Received on:

03 February 2021

Revised till:

05 August 2021

Accepted on:

06 August 2021

Publisher version published on:

08 September 2021

\begin{abstract}
Acid and base are a chemical material that contains facts, concepts, principles and procedures. This research aims to produce an e-module based on guided inquiry integrated virtual laboratory on acid-base material which is valid and practical. The development model used is the 4-D model. The validity test of the e-module was carried out by experts, namely 2 UNP chemistry lecturers, 1 UNP educational technology lecturer and 2 chemistry teachers, while the practicality test was carried out by 2 chemistry teachers and 18 students of SMAN 3 South Solok. The research instrument used was a validity questionnaire and a practicality questionnaire. The results of the validity and practicality test were analysed using the Aiken's $V$ formula, which obtained an average validity test with the high validity category, and the practicality test by teachers and students with high practicality categories. The result of the analysis of the answer to the e-module obtained an average the correct answer of $91,07 \%$ on the key questions, $92,38 \%$ on the worksheets and $91,9 \%$ on the evaluation sheets. Based on the research result, it can be concluded that the acid-base e-module is valid and practical.
\end{abstract}

\section{KEYWORDS}

4-D Model, Acid-base, E-Module, Guided Inquiry, Virtual Laboratory

\section{ABSTRAK}

Asam basa merupakan materi kimia yang mengandung fakta, konsep, prinsip dan prosedur. Tujuan penelitian ini adalah untuk menghasilkan e-modul berbasis inkuiri terbimbing terintegrasi virtual laboratory pada materi Asam basa yang valid dan praktis. Penelitian ini menggunakan model 4-D. Uji validitas dari e-modul dilakukan oleh lima orang ahli, yaitu dua orang dosen kimia UNP, satu orang dosen Teknologi Pendidikan UNP dan dua orang guru kimia, sedangkan uji praktikalitas dilakukan oleh dua orang guru kimia dan 18 orang siswa SMAN 3 Solok Selatan. Hasil uji validitas dan praktikalitas yang telah dianalisis menggunakan formula Aiken's V diperoleh nilai V dengan kategori tinggi. Sedangkan uji praktikalitas didapatkan hasil dengan kategori tinggi. Sedangkan dari hasil analisis jawaban pada e-modul diperoleh rata-rata jawaban yang benar adalah 91,07\% pada pertanyaan kunci, 92,38\% pada lembar kerja dan 91,9\% pada lembar evaluasi. Berdasarkan hasil penelitian dapat disimpulkan bahwa e-modul asam basa yang dikembangkan telah valid dan praktis.

KATA KUNCI

Asam Basa, E-Modul, Inkuiri Terbimbing, Model 4-D, Virtual Laboratory 


\section{PENDAHULUAN}

Asam basa adalah materi pada kurikulum 2013 yang merupakan materi di awal semester genap kelas XI SMA/MA. Materi Asam Basa terdiri atas pengetahuan faktual, konseptual, dan prosedural. Usaha peningkatan mutu pendidikan dilakukan pemerintah melalui pengembangan kurikulum ${ }^{[1]}$. Tahap implementasi kurikulum 2013 berfokus pada keaktifan siswa melalui proses ilmiah, dengan tujuan pembelajaran tidak hanya membina siswa yang memiliki pengetahuan dan kemampuan, tetapi juga siswa yang memiliki sikap dan keterampilan yang baik ${ }^{[2]}$.

Namun dalam kondisi saat ini, dapat dilihat bahwa pembelajaran di sekolah tidak dapat berjalan seperti biasanya. Peserta didik belajar mandiri di rumah dan tugas pembelajaran dikirimkan guru secara online, sehingga dengan menggunakan sistem pembelajaran seperti ini siswa akan kesulitan memahami materi pembelajaran dan soal latihan. Hal tersebut dapat diatasi dengan adanya bahan ajar yang didalamnya dilengkapi dengan penyajian materi pembelajaran, video, animasi, dan soal-soal latihan salah satunya yaitu e-modul ${ }^{[3]}$.

Keunggulan dari e-modul adalah e-modul dapat meningkatkan efisiensi dan fleksibilitas, dimana pembelajaran dapat dilakukan kapanpun, tidak bergantung waktu ${ }^{[4]}$. Dimana dalam e-modul dapat menampilkan video praktikum dan animasi pergerakan molekul ${ }^{[5]}$.

Modul elektronik adalah bahan ajar yang ditampilkan menggunakan perangkat elektronik seperti komputer dan android ${ }^{[6]}$. Modul elektronik dapat menumbuhkan minat siswa dalam belajar baik mandiri maupun berkelompok ${ }^{[7]}$. E-modul berasal dari huruf e- dan kata modul, yang berarti e- adalah elektronik, sedangkan modul Menurut Departemen Pendidikan Nasional (2008) adalah suatu materi pembelajaran yang disusun secara sistematis sesuai dengan tuntutan kurikulum dan dikemas dalam satuan pembelajaran terkecil sehingga memungkinkan untuk dipelajari secara mandiri dalam waktu tertentu ${ }^{[8]}$. $\begin{array}{cccr}\text { Model } & \text { inkuiri } & \text { merupakan } & \text { model } \\ \text { pengembangan } & \text { yang } & \text { digunakan } & \text { pada } \\ \text { pengembangan } & \text { modul } & \text { elektronik } & \text { yang }\end{array}$ mengharuskan siswa mampu menemukan sendiri dari jawaban yang dipertanyakan yang berorientasi pada siswa (student centered approach) ${ }^{[9]}$. Model pembelajaran inkuiri terbimbing meliputi lima tahap kegiatan yaitu orientasi, eksplorasi, pembentukan konsep, aplikasi dan penutup ${ }^{[10]}$. Model pembelajaran inkuiri terbimbing menuntut siswa untuk dapat menemukan konsep sendiri dalam belajar sehingga dapat meningkatkan keterampilan berpikir kritis siswa ${ }^{[11]}$ dan disertai proses penemuan konsep ${ }^{[12]}$.

Bahasan yang terdapat dalam ilmu kimia adalah mempelajari materi dan perubahannya. Ilmu kimia mengkaji tentang sifat-sifat zat, perubahan zat, (reaksi kimia), energi yang terlibat, hukum, prinsip dan teori ${ }^{[13]}$.
Konsep-konsep yang terdapat dalam materi kimia tidak efektif jika hanya dipelajari dengan teori saja, tetapi juga dengan melakukan kegiatan eksperimen atau percobaan ${ }^{[14]}$. Laboratorium virtual (virtual laboratory) ${ }^{[15]}$ merupakan media yang dapat digunakan untuk memahami pembelajaran serta dapat menjadi solusi akan ketidakterlaksanaan praktikum dan kekurangan peralatan yang digunakan di laboratorium untuk praktikum, sehingga virtual laboratory dapat membantu jika pelaksanaan praktikum tidak bisa dilakukan secara nyata ${ }^{[16]}$.

Berdasarkan hasil observasi di SMAN 3, SMAN 4, dan SMAN 6 Padang dapat diperoleh data 1) sebagian siswa masih kesulitan dalammemahami konsep asam basa serta perhitungan $\mathrm{pH}$ asam basa, 2) bahan ajar yang tersedia belum memungkinkan siswa belajar mandiri 3) bahan ajar berupa e-modul asam basa belum tersedia di sekolah untuk pembelajaran ${ }^{[17]}$.

Adapun tujuan dari penelitian ini adalah (1) Menghasilkan bahan ajar berbentuk E-Modul berbasis inkuiri terbimbing terintegrasi virtual laboratory pada materi asam basa kelas XI SMA/MA. (2) Menentukan tingkat validitas dan praktikalitas E-Modul berbasis inkuiri terbimbing terintegrasi virtual laboratory pada materi asam basa kelas XI SMA/MA.

Penelitian relevan dengan penelitian ini adalah penelitian yang dilakukan oleh Syukra menunjukkan validitas dan praktikalitas dari modul elektronik yang dikembangkan secara berturut-turut memiliki kevalidan sangat tinggi dengan rata-rata momen kappa 0,840. Pada uji praktikalitas guru 0,860 dan uji praktikalitas siswa 0,811 dengan kepraktisan sangat tinggi ${ }^{188}$. Sama halnya dengan penelitian Fadhilah yang menyatakan bahwa modul yang dikembangkan secara berturut turut memiliki kevalidan sangat tinggi dengan rata-rata momen kappa 0,830 dan kepraktisan sangat tinggi dengan momen kappa 0,810 pada uji praktikalitas guru dan 0,820 pada uji praktikalitas siswa ${ }^{[19]}$. Dari penelitian lainnya seperti penelitian Gunawan diperoleh bahwa model inkuiri terbimbing melalui laboratorium virtual memiliki pengaruh yang signifikan pada keterampilan proses sains terutama pada keterampilan berhipotesis, pelaksanaan praktikum dan berkomunikasi ${ }^{[20]}$.

\section{METODE}

Jenis penelitian dalam penelitian ini adalah penelitian dan pengembangan. Adapun model pengembangan yang digunakan adalah model 4-D (four-D) yang meliputi 4 tahapan yaitu define, design, develop, dan disseminate. Pada penelitian ini, hanya dilakukan sampai tahap pengembangan (develop) dengan melakukan uji validitas dan praktikalitas dari e-modul yang dikembangkan, sedangkan untuk tahap disseminate tidak dilakukan karena memerlukan waktu yang lama dan biaya yang besar. Untuk tahapan uji validitas dilakukan oleh lima orang ahli, yaitu 2 orang dosen Kimia FMIPA UNP, 1 orang dosen Teknologi Pendidikan, 
2 orang guru kimia, serta 18 orang peserta didik dari SMAN 3 Solok Selatan. Data yang diperoleh dianalisis dengan menggunakan indeks pengolahan data menggunakan formula indeks Aiken's V (V).

$$
\begin{gathered}
V=\frac{\sum s}{n(c-1)} \ldots \text { Persamaan } 1 \\
S=r-l o \ldots \text { Persamaan } 2
\end{gathered}
$$

Dengan $V$ adalah indeks kesepakatan rater, $s$ skor yang ditetapkan setiap rater dikurangi skor terendah dalam kategori yang dipakai (lihat Persamaan 2), dengan $r$ = skor kategori pilihan rater dan lo skor terendah dalam penskoran), $n$ banyaknya rater, dan $c$ banyaknya kategori yang dipilih rater ${ }^{[20]}$.

Tabel 1. Keputusan Berdasarkan Indeks Aiken's V (V).

\begin{tabular}{c|c} 
Interval & Kategori \\
\hline$\leqslant 0,4$ & Kurang \\
\hline $0,4<\mathrm{V} \leqslant 0,8$ & Sedang \\
\hline $0,8<\mathrm{V}$ & Valid
\end{tabular}

\section{HASIL DAN DISKUSI}

\subsection{Tahap Define (Pendefinisian)}

\subsubsection{Analisis ujung depan}

Analisis ujung depan dilakukan agar dapat diketahui permasalahan utama yang dialami terhadap pembelajaran kimia. Terutama terkait bahan ajar yang digunakan pada materi Asam Basa yang digunakan dalam pembelajaran di sekolah. Pada analisis ujung depan, dari hasil wawancara dan pengisian angket diperoleh bahwa siswa kurang tertarik dengan bahan ajar yang digunakan, siswa masih kesulitan dalam pembelajaran kimia, dan siswa masih kesulitan dalam memahami konsep asam basa.

\subsubsection{Analisis Peserta Didik (learner analysis)}

Analisis siswa bertujuan untuk menemukan dan memahami cara siswa dalam belajar. Berdasarkan hasil analisis peserta didik, ditemukan bahwa model inkuiri terbimbing cocok dipakai dalam belajar terutama pada materi asam basa karena model ini membantu siswa untuk memahami dan menemukan konsep pembelajaran, sehingga siswa mampu memahami konsep. Selain itu, e-modul yang didalamnya terdapat animasi, gambar, video animasi yang dapat menarik minat siswa untuk belajar.

\subsubsection{Analisis Tugas}

Analisis tugas dilakukan untuk menentukan Indikator Pencapaian Kompetensi (IPK) dengan cara menganalisis Kompetensi Dasar (KD) 3.10 pada kelas XI kurikulum 2013 revisi 2018.

\subsubsection{Analisis Konsep}

Analisis konsep dilakukan dengan mengidentifikasi konsep-konsep pokok yang dibutuhkan pada materi asam basa.

\subsubsection{Analisis Tujuan Pembelajaran}

Analisis tujuan pembelajaran didasarkan pada hasil analisis Kompetensi Dasar (KD) dan Indikator Pencapaian Kompetensi (IPK), sehingga tujuan pembelajaran dapat dirumuskan untuk dicapai dalam proses pembelajaran.

\subsection{Tahap Design (Perancangan)}

Pengembangan e-modul ini diolah dan didesain dengan menggunakan beberapa aplikasi pada komputer. Aplikasi-aplikasi tersebut yaitu Microsoft Word 2010, Microsoft Publisher 2010, Unity 3D, Microsoft Powerpoint 2010, Paint 3D, Adobe Photoshop dan Flip PDF Professional. Aplikasi Microsoft Word 2010 digunakan untuk menyusun draf awal komponen-komponen e-modul yang kemudian disunting dengan menggunakan Microsoft Publisher 2010. Aplikasi Flip PDF Professional digunakan untuk mengubah tampilan e-modul ke dalam bentuk digital karena tidak hanya memuat gambar dan teks saja namun dapat memuat video, animasi, serta siswa dapat menjawab pertanyaan secara langsung pada e-modul.

Perancangan e-modul ini disesuaikan dengan panduan penulisan pada buku Panduan Pengembangan Bahan Ajar yang disarankan oleh Suryosubroto tentang sistem pengajaran dengan modul, namun pada modul elektronik ini tidak terdapat kunci lembaran kerja dan kunci lembaran evaluasi karena e-modul memberikan feedback langsung kepada siswa ketika siswa mengisi jawaban di lembaran kerja dan lembaran evaluasi. Adapun tampilan rancangan e-modul dapat dilihat pada Gambar 1 dan Gambar 2 , serta rancangan virtual laboratory dapat dilihat pada Gambar 3 dan Gambar 4.

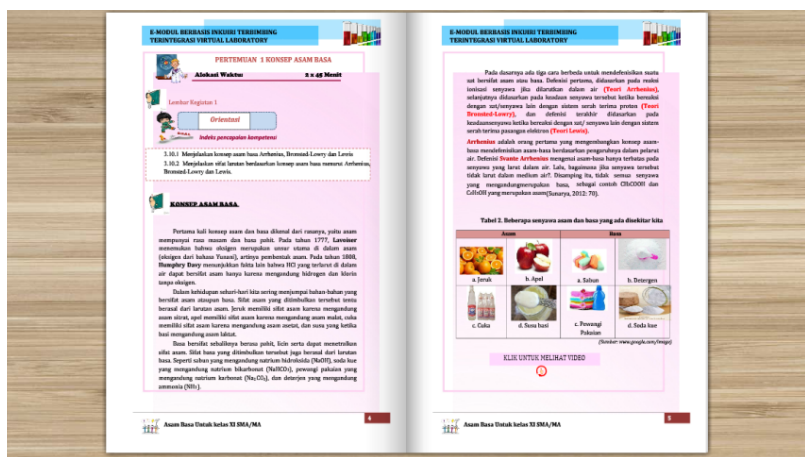

Gambar 1. Tampilan E-Modul pada Tahap Orientasi.

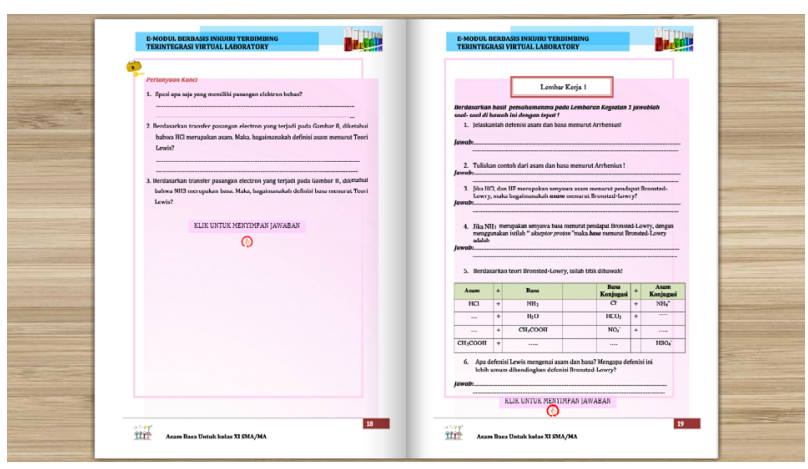

Gambar 2. Tampilan Lembar Kerja pada E-Modul. 


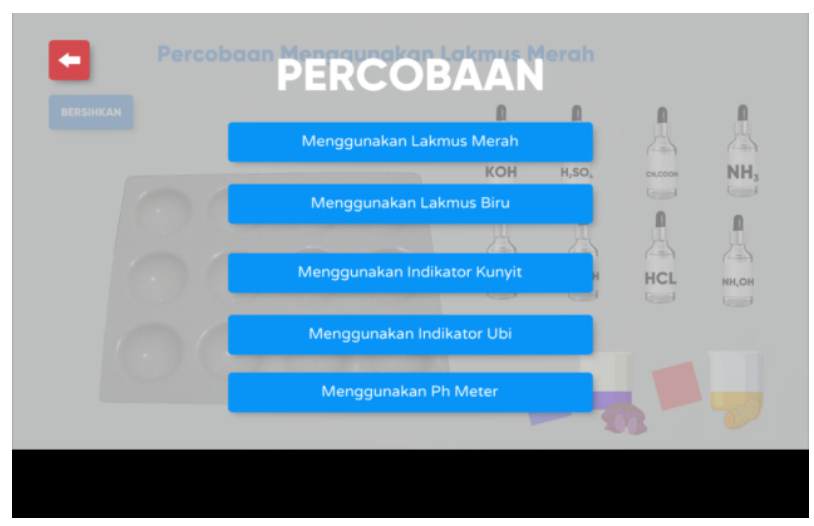

Gambar 3. Tampilan Judul dan Cover Virtual Laboratory.

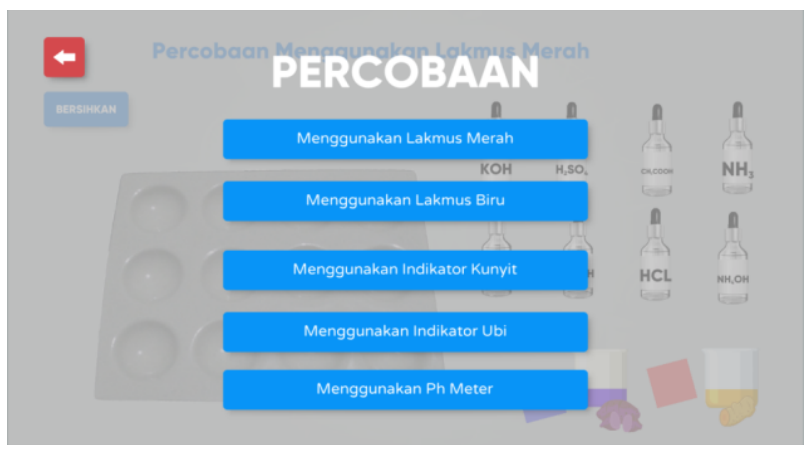

Gambar 4. Tampilan Percobaan Virtual Laboratory.

\subsection{Tahap Pengembangan (Develop)}

\subsubsection{Uji Validitas}

Uji validitas dilakukan untuk mengetahui penilaian dari rancangan produk atau bahan ajar yang dilakukan oleh ahli yaitu dosen Kimia, dosen Teknologi Pendidikan dan guru Kimia. Validitas e-modul asam basa dilakukan oleh lima orang validator. Validitas e-modul bertujuan untuk mengetahui penilaian dan tingkat kevalidan dari e-modul yang dikembangkan. Berdasarkan hasil analisis data penilaian e-modul menggunakan formula indeks Aiken's V diperoleh hasil uji validitas terhadap 5 orang validator seperti yang terlihat seperti pada Tabel 2 .

Tabel 2. Hasil Rata-rata Aiken's V oleh Validator.

\begin{tabular}{c|c|c} 
Komponen Penilaian & $\mathbf{V}$ & Kategori \\
\hline Kelayakan Isi & 0,880 & Tinggi \\
\hline Penyajian & 0,770 & Sedang \\
\hline Kebahasaan & 0,810 & Tinggi \\
\hline Kegrafikaan & 0,810 & Tinggi
\end{tabular}

Dari hasil analisis data penilaian dari keempat validator terhadap kelayakan isi e-modul asam basa diperoleh rata-rata Aiken's V adalah 0,810 dengan kategori kevalidan tinggi. Hal ini berarti komponen e-modul Asam Basa telah memenuhi tuntutan Kompetensi Dasar 3.10 dan 4.10, sedangkan untuk validator ahli media didapatkan data dari pengisian angket oleh dosen teknologi pendidikan bahwa gambar, animasi serta virtual laboratory pada e-modul sudah sesuai dan jelas, keterpaduan pemilihan warna serta jenis teks sudah sesuai, serta penggunaan e-modul mudah dipelajari. Sedangkan untuk ruang entri jawaban tidak bisa diklik karena e-modul digunakan di komputer lain sehingga link jawabannya tidak bisa diklik.

Komponen penyajian e-modul asam basa memiliki rata-rata indeks Aiken's $\mathrm{V}$ sebesar 0,770 dengan kevalidan tinggi. Bahan ajar yang dikembangkan sesuai dengan IPK yang telah dirumuskan secara sistematika dengan tahapantahapan pembelajaran inkuiri terbimbing, serta virtual laboratory sudah sesuai dengan konsep asam basa.

Komponen kebahasaan e-modul asam basa diperoleh indeks Aiken's V sebesar 0,810 dengan kevalidan tinggi. Dari data ditunjukkan bahwa bahasa yang digunakan pada e-modul asam basa yang telah dikembangkan sudah sesuai dengan EBI, mudah dikomunikasikan, serta mudah dimengerti. Modul elektronik yang baik menggunakan kalimat sederhana sehingga informasi yang terdapat dalam e-modul dapat tersampaikan dengan jelas.

Komponen kegrafikan memiliki rata-rata indeks Aiken's V yaitu 0,810 dengan kategori tinggi. E-modul asam basa yang dikembangkan dari tampilan e-modul secara keseluruhan telah menarik dan sesuai, sehingga dapat membantu dalam proses pembelajaran ${ }^{[15]}$. Hasil data validasi menunjukkan bahwa e-modul asam basa yang didapatkan telah valid.

Dari pengisian angket yang dilakukan oleh 2 orang guru kimia dan 18 orang siswa SMAN 3 Solok Selatan diperoleh rata-rata indeks Aiken's V 0,820 dengan kategori tinggi dan oleh 18 orang siswa kelas XII diperoleh 0,890 dengan kategori kepraktisan tinggi.

Sementara pada analisis penilaian komponen kemudahan penggunaan pada e-modul diperoleh rata-rata indeks Aiken's V yaitu 0,830 dengan kategori tinggi oleh guru dan siswa diperoleh 0,880 dengan kategori kepraktisan tinggi. Hal ini menunjukkan bahwa e-modul yang dikembangkan sederhana dan dapat digunakan siswa.

Pada analisis penilaian komponen efisiensi waktu pembelajaran, diperoleh rata-rata indeks Aiken's V yaitu 0,750 dengan kategori kepraktisan sedang oleh guru dan siswa 0,880 dengan kategori kepraktisan tinggi. Jadi, e-modul dapat menjadikan pembelajaran lebih efisien.

Tabel 3. Hasil Analisis Uji Praktikalitas Guru.

\begin{tabular}{c|c|c} 
Komponen Penilaian & $\mathbf{V}$ & Kategori \\
\hline Kelayakan Isi & 0,880 & Tinggi \\
\hline Penyajian & 0,750 & Sedang \\
\hline Kebahasaan & 0,810 & Tinggi \\
\hline Kegrafikaan & 0,840 & Tinggi \\
\hline Manfaat & 0,819 & Tinggi
\end{tabular}


Tabel 4. Hasil Analisis Uji Praktikalitas Siswa.

\begin{tabular}{c|c|c} 
Komponen Penilaian & $\mathbf{V}$ & Kategori \\
\hline Kelayakan Isi & 0,880 & Tinggi \\
\hline Penyajian & 0,880 & Tinggi \\
\hline Kebahasaan & 0,880 & Tinggi \\
\hline Kegrafikaan & 0,900 & Tinggi \\
\hline Manfaat & 0,880 & Tinggi
\end{tabular}

\section{Hasil Analisis Jawaban Siswa Terhadap Pertanyaan E-Modul}

\author{
Aspek \\ yang dianalisis \\ Pertanyaan Kunci \\ Lembar Kerja \\ Lembar Evaluasi
}

Persentase

(dalam \%)

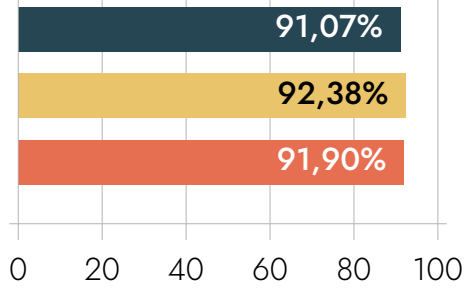

Gambar 5. Hasil Analisis Jawaban Siswa.

Pada analisis penilaian komponen kebahasaan oleh guru diperoleh rata-rata indeks Aiken's V 0,8125 dengan kategori kepraktisan tinggi dan oleh siswa 0,900 dengan kategori kepraktisan tinggi. E-modul yang dikembangkan sesuai dengan EBI. Sedangkan pada analisis penilaian komponen kegrafikan oleh guru diperoleh rata-rata indeks Aiken's V yaitu 0,840 dengan kategori tinggi dan oleh siswa yaitu 0,900 dengan kategori tinggi. Huruf dan gambar e-modul jelas dan mudah diamati oleh siswa. Sedangkan pada analisis penilaian komponen manfaat e-modul oleh guru diperoleh rata-rata indeks Aiken's V yaitu 0,819 dengan kategori tinggi dan oleh siswa diperoleh 0,880 dengan kategori tinggi. Hal ini menunjukkan e-modul Asam Basa dapat meminimalkan guru menjelaskan materi secara berulang serta menunjang siswa belajar secara mandiri.

Berdasarkan keseluruhan hasil uji praktikalitas e-modul Asam Basa praktis digunakan serta guru dan siswa dapat terbantu dalam belajar. Dari hasil uji praktikalitas bahwa e-modul Asam Basa ini mudah digunakan, gambar dan teks jelas dan mudah dibaca, video dan animasi dapat membuat siswa tertarik dan lebih cepat memahami materi.

Berdasarkan hasil analisis jawaban pertanyaan e-modul oleh siswa kelas XII SMAN 3 Solok Selatan hasil analisis jawaban siswa terhadap pertanyaan pada lembar kerja diperoleh siswa telah mampu menjawab pertanyaan pada lembar kerja 1 sebesar 92,7\%, lembar kerja 2 93,6\%, lembar kerja 3.1 91,6\%, lembar kerja 3.2 90,2\%, lembar kerja 4 93,8\% dan pertanyaan pada lembar evaluasi sebesar $91,9 \%$. Hal ini menunjukkan materi Asam Basa akan lebih mudah dipahami pada modul elektronik sehingga siswa dapat menjawab soal dengan benar.

\section{SIMPULAN}

Dari penelitian yang telah dilakukan dapat disimpulkan bahwa e-modul berbasis inkuiri terbimbing terintegrasi virtual laboratory pada materi Asam Basa kelas XI SMA/MA yang dihasilkan valid dan praktis.

\section{REFERENSI}

1. Bahri S. Pengembangan Kurikulum Dasar Dan Tujuannya. Jurnal Ilmiah Islam Futura. 2011;11(1):15.

2. Fitriani A. Implementasi Pembelajaran Yang Efektif Bagi Siswa Madrasah Ibtidaiyah. ArRiayah: Jurnal Pendidikan Dasar. 2019;3(1):45.

3. Simbolon DH, Sahyar. Pengaruh Model Pembelajaran Inkuiri Terbimbing Berbasis Eksperimen Riil dan Laboratorium Virtual terhadap Hasil Belajar Fisika Siswa. Jurnal Pendidikan dan Kebudayaan. 2015;21(3):299.

4. Yolanda SE, Gunawan G, Sutrio S. Pengaruh Model Pembelajaran Inkuiri Terbimbing Berbantuan Video Kontekstual Terhadap Penguasaan Konsep Fisika Peserta Didik. Jurnal Pendidikan Fisika dan Teknologi. 2019;5(2):341.

5. Swandi A, Nurul HS, Irsan LJ. Pengembangan Media Pembelajaran Laboratorium Virtual untuk Mengatasi Miskonsepsi Pada Materi Fisika Inti di SMAN 1 Binamu, Jeneponto. Jurnal Fisika Indonesia. 2014;18(52):20-24.

6. Utami WS. Tuntutan Refoemasi Pembelajaran Dalam Kurikulum 2013. Jurnal Geografi. 2014;12(2).

7. Sujanem R, Suwindra INP, Suswandi I. Efektivitas E-Modul Fisinberma Dalam Ujicoba Terbatas Untuk Meningkatkan Keterampilan Berpikir Kritis Siswa SMAN 2 Singaraja. Seminar Nasional Riset Inovatif. 2018;(2):260-6.

8. Wijayanti W. Student Centered; Paradigma Baru Inovasi Pembelajaran. Majalah Ilmiah Pembelajaran. 2011;7(1):64-75.

9. Hanson DM. Designing Process-Oriented GuidedInquiry Activities. In Faculty Guidedbook: A Comprehensive Tool For Improving Faculty Performance, ed. S. W. Beyerlein and D. K. Apple. Lisle, IL: Pacific Crest; 2005.

10. Muspawi M, Suratno, Ridwan. Upaya Peningkatan Higher Order Thinking Skills (HOTS) Siswa Melalui Penerapan Model Inquiri di SMA Negeri 9 Tanjung Jabung Timur. Jurnal Ilmiah Universitas Batanghari. 2019;19(2):208-214.

11. Pratiwi KF, Wijayati N, Mahatmanti FW, Marsudi M. Pengaruh Model Pembelajaran Inkuiri Terbimbing Berbasis Penilaian Autentik Terhadap Hasil Belajar. Jurnal Inovasi Pendidikan Kimia. 2014;13(1):2337-2384. 
12. Fajrin S, Haetami A, Marhadi MA. Identifikasi Kesulitan Belajar Siswa Pada Materi Pokok Larutan Asam dan Basa di Kelas XI IPA 2 SMA Negeri 1 Wolowa Kabupaten Buton. Jurnal Pendidikan Kimia FKIP Universitas Halu Oleo. 2020;5(1).

13. Jaya H. Pengembangan Laboratorium Virtual Untuk Kegiatan Praktikum Dan Memfasilitasi Pendidikan Karakter di SMK. Jurnal Pendidikan Vokasi. 2012;2(1).

14. Hikmah N, Saridewi N, Agung S. Penerapan Laboratorium Virtual untuk Meningkatkan Pemahaman Konsep Siswa. EduChemia (Jurnal Kimia dan Pendidikan). 2017;2(2):186-195.

15. Yusuf I, Widyaningsih SW, Purwati D. Pengembangan Perangkat Pembelajaran Fisika Modern Berbasis Media Laboratorium Virtual Berdasarkan Paradigma Pembelajaran Abad 21 dan Kurikulum 2013. Pancaran Pendidikan. 2015;4(2):189-200.

16. Tania L, Susilowibowo J. Pengembangan Bahan Ajar E-Modul Sebagai Pendukung Pembelajaran Kurikulum 2013 Pada Materi Ayat Jurnal Penyesuaian Perusahaan Jasa Siswa Kelas X Akuntansi Smk Negeri 1 Surabaya. Jurnal Pendidikan Akuntansi. 2017;5(2).

17. Syukra H, Andromeda. Pengembangan E-Modul Kesetimbangan Kimia Berbasis Inkuiri Terbimbing Terintegrasi Virtual Laboratory Untuk SMA/MA. Ranah Research Journal of Multidicsiplinary Research and Development. 2019;1(4):877-886.

18. Fadhillah F, Andromeda A. Validitas dan Praktikalitas E-Modul Berbasis Inkuiri Terbimbing Terintegrasi Laboratorium Virtual pada Materi Hidrolisis Garam kelas XI SMA/MA. Jurnal Eksakta Pendidikan. 2020;4(2):179-188.

19. Gunawan $\mathrm{G}$, Harjono A, Hermansyah $\mathrm{H}$, Herayati L. Guided Inquiry Model Through Virtual Laboratory To Enhance Students' Science Process Skills On Heat Concept. Cakrawala Pendidikan. 2019;38(2):259-268.

20. Retnawati H. Analisis Kuantitatif Instrumen Penelitian. Parama Publishing; 2016. 